\title{
Energy Analysis of Steam Cycle Efficiency with Feed Water Heater Modification (Case Study: PT. Pertamina EP Asset 1 Field Lirik)
}

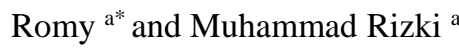 \\ a) Mechanical Engineering, Universitas Riau, Indonesia \\ *Corresponding author: romy@eng.unri.ac.id, muhammad.rizki7775@student.unri.aci.id
}

\section{Paper History}

Received: 15-October-2021

Received in revised form: $30-$ October-2021

Accepted: 30-November-2021

\begin{abstract}
The increasing energy efficiency program will decrease the consumption of energy. If these improvements are carried out together, it will certainly ensure energy reliability for a sustainable and better future. The aim of this paper was to investigate the possibility of increasing efficiency in the crude oil heating system at PT. Pertamina EP Asset 1 Lirik Field. The research method was done by modification the steam cycle using the close and open Feed Water Heater (FWH). As result, the efficiency of steam cycle of close FWH increased $2.53 \%$ and $2.78 \%$ for open FWH. While the efficiency of the steam cycle in the initial conditions was $36.74 \%$.
\end{abstract}

KEY WORDS: Energy analysis, Feed water heater, Efficiency improvement.

\subsection{INTRODUCTION}

Improving energy efficiency is one of the main problems of developed countries around the world, because it is related to sustainable development. With energy efficiency improvement programs, the amount of energy needs to be reduced [1]. If these improvements are carried out, it will certainly ensure energy reliability for a sustainable and better future [2-3]. To determine the accuracy of the efficiency of a power plant, it is not enough to refer only to energy efficiency as it is based on the first law of thermodynamics, but it needs to be combined with an exergy approach based on the second law of thermodynamics [4]. The limitations and the decreasing amount of energy derived from fossil fuels demands that the industry, in this case PT. Pertamina EP Asset 1 Lirik Field to save boiler fuel. Savings does not mean reducing energy consumption in the production of a refinery but rather using renewable energy and or increasing efficiency in energy use.

Increasing the efficiency of energy use can be done by updating equipment with the latest technology or improving the operating conditions of existing equipment. The activity of improving the operating conditions of energy generating machines should be an annual activity in order to reduce production costs, because this activity can be carried out with relatively small capital costs. In 2018 an analysis was carried out to increase efficiency using the close FWH method on a steam turbine power plant and there was an increase in cycle efficiency to $50 \%$ when compared to the ideal condition, the efficiency was only $37 \%$ [5]. The same thing was also carried out in 2019 where research conducted an analysis to increase efficiency by using the close FWH method on the power plant. The research using three FWHs, the cycle efficiency value increased by $7 \%$, namely at when the ideal state of cycle efficiency was only $31.73 \%$ to $38.73 \%$ [6]. From the explanation above, the researcher is interested in analyzing the efficiency increase by using a feed water heater in the crude oil heating system in the PPP Sei Karas unit PT. Pertamina EP Asset 1 Lirik Field.

In various power generating systems, attention is focused on converting the internal energy of the hydrocarbon fuel molecules into electrical or mechanical energy [7]. In the second law of thermodynamics, an irreversible process produces entropy, while a reversible process is a very balanced change, with the system in equilibrium with its surroundings at each stage. A reversible process does not produce entropy, but only transfer entropy from one isolated part of the system to another [8]. The boiler basically consists of a drum that is closed at the end and the base and in its development is equipped with a fire pipe and water pipe. Many people classify steam boilers depending on their respective points of view [9$10]$.

Calculating boiler efficiency can be obtained by two methods, namely the indirect method and the direct method. In this study, the efficiency calculation uses direct calculations where the efficiency calculation with the direct boiler method is a boiler efficiency calculation that uses a comparison between the working fluid (water and steam) with the energy contained in the fuel. The equations used to calculate boiler efficiency 
with the direct method are as follows [11]:

$$
\begin{aligned}
& \text { Boiler efficiency }=\frac{Q_{\text {out }}}{Q_{\text {in }}} \times 100 \% \\
& \eta_{\text {boiler }}=\frac{\text { Steam flow rate } \times(\text { hg }-h f)}{(\text { Fuel flow rate }) \times L H V} \times 100
\end{aligned}
$$

\subsection{Rankine Cycle}

The cycle is a series of processes which start from a condition level that will return to the original condition level and always repeats itself. In steam power plants, the fluid that undergoes these processes is water. Water functions as a working fluid; water in its work cycle undergoes processes of heating, evaporation, expansion, cooling, and compression. The standard cycle of a steam power plant is the Rankine cycle. The simple Rankine cycle consists of four main components, namely pump, boiler, turbine and condenser. The thermal efficiency equation of the ideal Rankine cycle [12]:

$$
\begin{aligned}
\eta_{\text {th }}=\frac{W_{\text {net }}}{Q_{\text {in }}} & =\frac{W_{T}-W_{P}}{Q_{\text {in }}}=\frac{Q_{\text {in }}-Q_{\text {out }}}{Q_{\text {in }}} \\
& =1-\frac{Q_{\text {out }}}{Q_{\text {in }}}
\end{aligned}
$$

\subsection{RESEARCH METHOD}

In this study, prior to the energy analysis calculations were carried out on the PT. Pertamina EP Asset 1 Lirik Field. The energy calculation diagram is depicted in Figure 1.

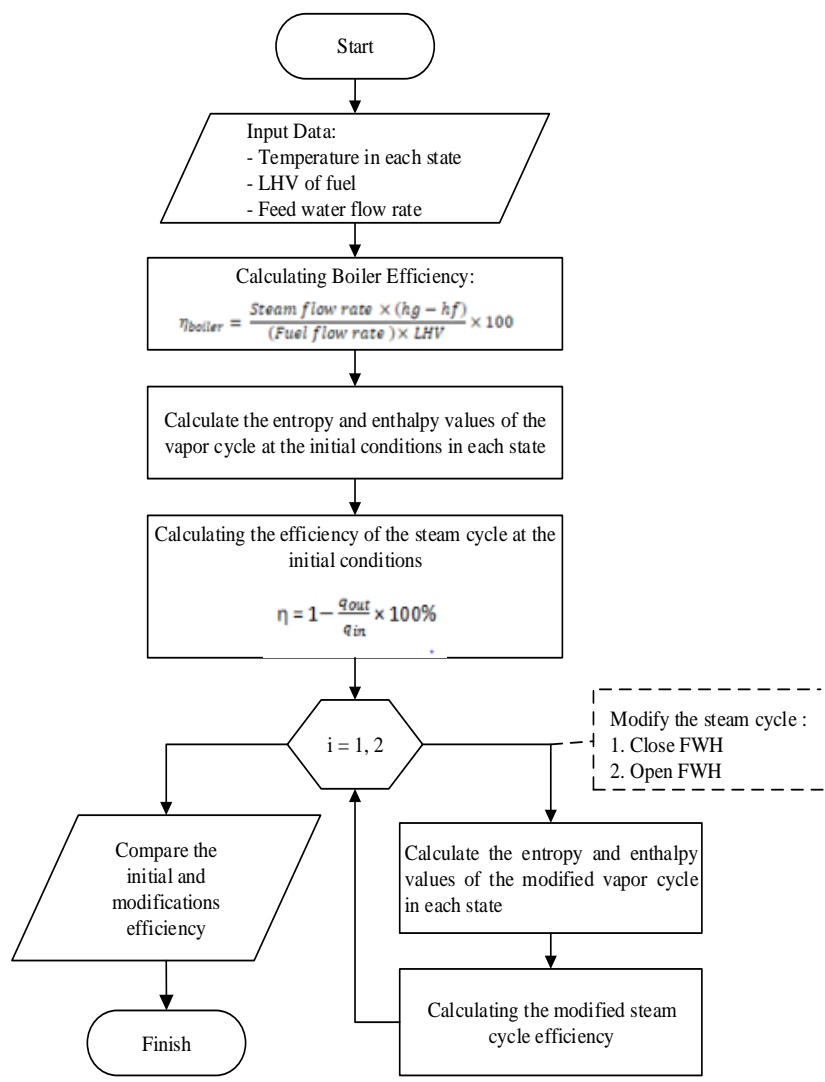

Figure 1: Calculation Flowchart
In the initial conditions, the feed water of flow rate, temperature and pressure for each state were the actual temperature based on direct measurement data. From the temperature and pressure operating data, the enthalpy of each state was calculated. The LHV (Lower Heating Value) was based on reference of natural gas as boiler fuel. For modified conditions, open and close of FWH, the state of 3, 4 and 5 were the same as the initial conditions, while other conditions must be calculated.

The first step calculation began with calculating the thermal efficiency of the boiler, which would be used later to calculate fuel consumption. Then, the next step was to calculate the efficiency of the steam cycle for each steam cycle and compare each result to get the recommended cycle. And lastly, calculate the fuel consumption of each steam cycle to find out the fuel economy. In this calculation, it was assumed that the boiler efficiency was constant. Therefore, the flow rate can be heated the crude oil.

\subsection{Steam Cycle Modification}

In this study, to increase the efficiency of the cycle, it was done by modifying the steam cycle by using the regenerative cycle of FWH:

1. Close Regenerative Cycle of FWH

2. Open Regenerative Cycle of FWH

\subsection{RESULT AND DISCUSSION}

\subsection{Initial States of Energy Analysis}

Analysis of the efficiency of the fire tube boiler was carried out on the boiler in production collection center unit of PT. Pertamina EP Asset 1 Lirik Field. The results of the analysis were taken at the conditions when data collection, using the input/output (direct) method. The energy analysis used the data on 27 June 2021, during 24-hour operation. As example, calculations would be made for conditions at 08:00 WIB, which is shown in Table 1.

Table 1: Fluid Temperature

\begin{tabular}{lcc}
\hline \multicolumn{1}{c}{ Substance } & State & Temperature $\left({ }^{\circ} \mathbf{C}\right)$ \\
\hline Water in Pump & 1 & 30 \\
Water in Boiler & 2 & 33 \\
Steam in HE & 3 & 115 \\
Steam Out HE & 4 & 90 \\
Steam Out Separator & 5 & 69 \\
\hline
\end{tabular}

The feed water mass flow rate was calculated from the average debit is as following:

$$
\begin{aligned}
& \dot{m}_{\text {feedwater }}=\rho_{\text {feedwater }} \times \dot{V}_{\text {feedwater }} \\
&=996 \frac{\mathrm{kg}}{\mathrm{m}^{3} x} 0.0002 \frac{\mathrm{m}^{3}}{\mathrm{~s}} \\
&=0.2 \mathrm{~kg} / \mathrm{s} \\
& \dot{m}_{\text {water }}-\dot{m}_{\text {steam }}=0.2 \frac{\mathrm{kg}}{\mathrm{s}}
\end{aligned}
$$

The efficiency of the boiler was calculated by equation 2 , where the LHV is $49,935 \mathrm{~kJ} / \mathrm{kg}$. 


$$
\begin{aligned}
& \eta_{\text {Boiler }}=\frac{\left(\frac{0,2 \mathrm{~kg}}{\mathrm{~s}}\right) \times\left(2698.60 \frac{\mathrm{kJ}}{\mathrm{kg}}-138.33 \frac{\mathrm{kJ}}{\mathrm{kg}}\right)}{\left(0.012 \frac{\mathrm{kg}}{\mathrm{s}}\right) \times 49.935 \frac{\mathrm{kJ}}{\mathrm{kg}}} \times 100 \% \\
& \eta_{\text {Boiler }}=85.46 \%
\end{aligned}
$$

Figure 2 is a schematic of the steam cycle line at PT Pertamina EP Asset 1 Lirik Field. To calculate the efficiency of the cycle, the enthalpy value of each state is needed. By using Figure 3, the enthalpy of each state is calculated as follow:

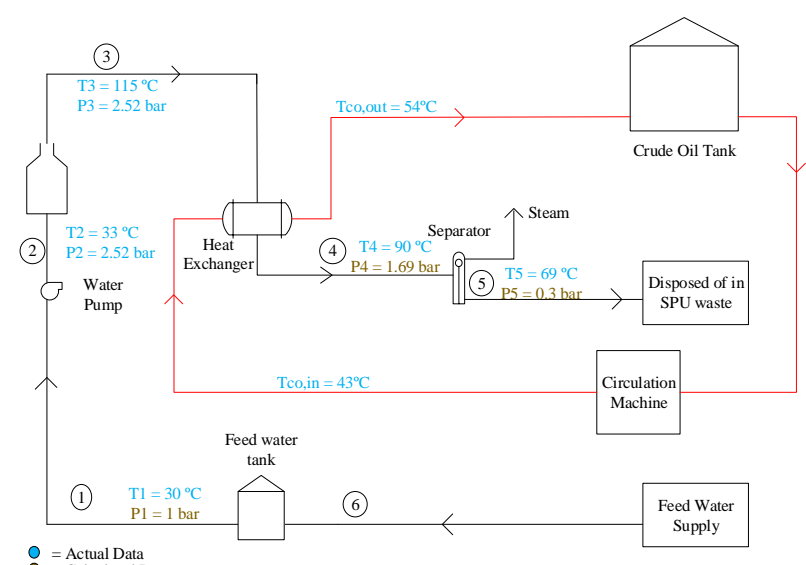

Figure 2: Steam Cycle at Existing Condition (Initial Condition)

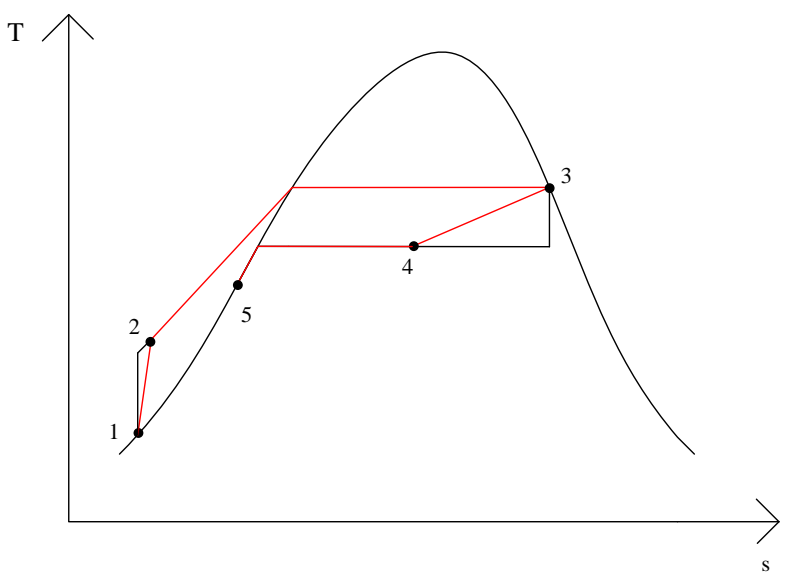

Figure 3: Initial Condition T-s Diagram

The value of the steam cycle efficiency is expressed in the form of heat transfer using the ratio of the amount of heat out to the heat entering the boiler.

State 1:

State 1 was in a state of saturated water $\mathrm{T}_{1}=30^{\circ} \mathrm{C}$.

Table 2: Enthalpy and Entropy Values at $T_{1}$

\begin{tabular}{ccc}
\hline $\mathrm{T}\left({ }^{\circ} \mathrm{C}\right)$ & $\mathrm{h}_{1}(\mathrm{~kJ} / \mathrm{kg})$ & $\mathrm{s}_{1}(\mathrm{~kJ} / \mathrm{kg} \cdot \mathrm{K})$ \\
\hline 30 & 125.79 & 0.4369 \\
\hline
\end{tabular}

State 2:

State 2 was in saturated water $\mathrm{T}_{2}=33^{\circ} \mathrm{C}$.
Table 3: Enthalpy and Entropy Values at $\mathrm{T}_{2}$

\begin{tabular}{ccc}
\hline $\mathrm{T}\left({ }^{\circ} \mathrm{C}\right)$ & $\mathrm{h}_{2}(\mathrm{~kJ} / \mathrm{kg})$ & $\mathrm{s}_{2}(\mathrm{~kJ} / \mathrm{kg} \cdot \mathrm{K})$ \\
\hline 30 & 125.74 & 0.4368 \\
33 & 138.33 & 0.4781 \\
35 & 146.64 & 0.5051 \\
\hline
\end{tabular}

State 3:

State 3 was in saturated vapor $\mathrm{T}_{3}=115^{\circ} \mathrm{C}$.

Table 4: Enthalpy and Entropy Values at $\mathrm{T}_{3}$

\begin{tabular}{ccc}
\hline $\mathrm{T}\left({ }^{\circ} \mathrm{C}\right)$ & $\mathrm{h}(\mathrm{kJ} / \mathrm{kg})$ & $\mathrm{s}(\mathrm{kJ} / \mathrm{kg} . \mathrm{K})$ \\
\hline 115 & 2698.6 & 5.7092 \\
\hline
\end{tabular}

State 4:

To find out the enthalpy in state 4, the law of conservation of energy can be used. Energy required in the heat exchanger:

$$
\begin{aligned}
\dot{E}_{\text {Crudeoil }}=\dot{E}_{\text {Steam }} & \\
\dot{m}_{\text {Crudeoul }} x C_{p}\left(T_{\text {out }}-T_{\text {in }}\right) & =\dot{m}_{4}\left(h_{4}-h_{5}\right) \\
1745.20 & =h_{4}
\end{aligned}
$$

Where, $\dot{V}_{\text {Crudeoil }}=90.85 \frac{m^{3}}{h}$ (specification of circulating machine)

State 5:

State 5 is in saturated water $\mathrm{T}_{5}=69^{\circ} \mathrm{C}$.

Table 5: Enthalpy and Entropy Values at $\mathrm{T}_{5}$

\begin{tabular}{ccc}
\hline $\mathrm{T}\left({ }^{\circ} \mathrm{C}\right)$ & $\mathrm{h}(\mathrm{kJ} / \mathrm{kg})$ & $\mathrm{s}(\mathrm{kJ} / \mathrm{kg} . \mathrm{K})$ \\
\hline 65 & 272.12 & 0.8937 \\
69 & 288.88 & 0.9428 \\
70 & 293.07 & 0.9551 \\
\hline
\end{tabular}

The mass flow rate at state 5 was $42 \%$ of the mass flow rate at state 4 , then the mass flow rate at state 5 was $0.2 \mathrm{~kg} / \mathrm{s}$. The $42 \%$ $=0.08 \mathrm{~kg} / \mathrm{s}$.

Heat in and out:

$$
\begin{aligned}
q_{\text {in }} & =\left(h_{3}-h_{2}\right) \\
& =2560.27 \frac{\mathrm{kJ}}{\mathrm{kg}} \\
q_{\text {out }} & =\left(h_{4}-h_{1}\right) \\
& =1609.46 \frac{\mathrm{kJ}}{\mathrm{kg}} \\
w_{\text {net }} & =q_{\text {in }}-q_{\text {out }} \\
& =940.81 \frac{\mathrm{kJ}}{\mathrm{kg}}
\end{aligned}
$$

Then the steam cycle efficiency of the initial condition:

$$
\begin{aligned}
\eta_{\text {Steamcycle }} & =\frac{w_{\text {net }}}{q_{\text {in }}} \times 100 \% \\
& =36.74 \%
\end{aligned}
$$




\subsection{Energy Analysis Close FWH Method}

In the modified condition, the steam that was previously discharged from the heat exchanger is put into the close FWH (Figure 4). To calculate the efficiency of the cycle, the enthalpy value of each state is needed. By using Figure 5, for the modified state there has been a temperature change marked with the symbol ('), then the enthalpy of each state can be seen in Figure 5.

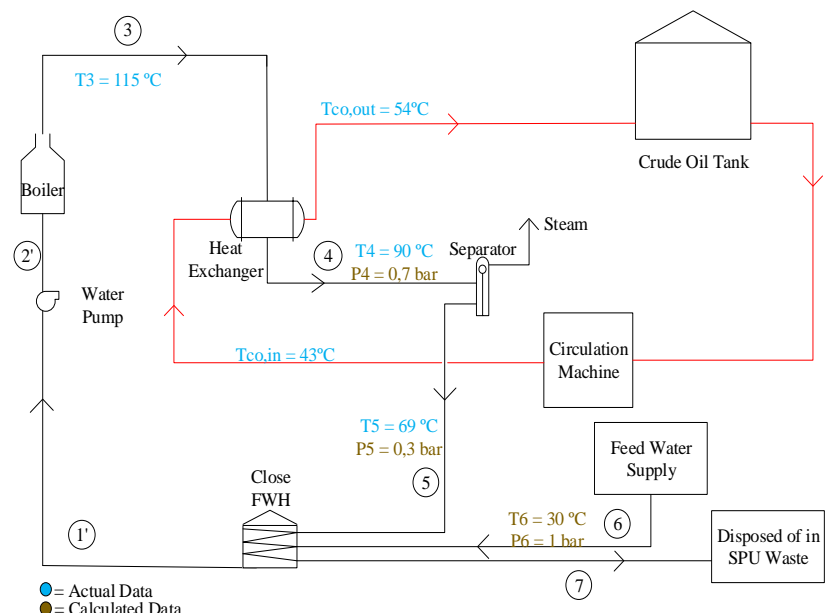

Figure 4: Modification of the Steam Cycle Using Close of FWH Method

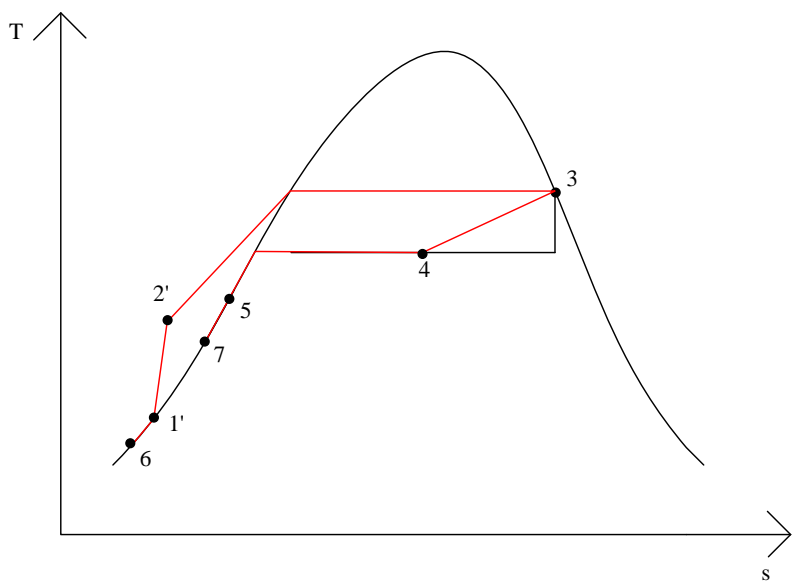

Figure 5: T-s Diagram Modified Close FWH

State 1':

State 1' was in a saturated water condition, the temperature at state $1^{\prime}$ was planned to increase by $15^{\circ} \mathrm{C}$ then,

$\mathrm{T} 7 \approx \mathrm{T} 1$ and $\mathrm{T} 1^{\prime}=\mathrm{T} 7+15^{\circ} \mathrm{C}=45^{\circ} \mathrm{C}$

Table 6: Enthalpy and Entropy Values at $\mathrm{T}_{1}$,

\begin{tabular}{ccc}
\hline $\mathrm{T}\left({ }^{\circ} \mathrm{C}\right)$ & $\mathrm{h}(\mathrm{kJ} / \mathrm{kg})$ & $\mathrm{s}(\mathrm{kJ} / \mathrm{kg} . \mathrm{K})$ \\
\hline 45 & 188.44 & 0.6386 \\
\hline
\end{tabular}

State 2':

State $2^{\prime}$ was in a saturated water condition. To calculate the enthalpy in state 2', the law of conservation of energy was used. The $\mathrm{Wp}$ value used when calculating the initial conditions.

$$
\begin{gathered}
\dot{m}_{1} h_{2^{\prime}}=\dot{m}_{1} h_{1^{\prime}}+W_{p} \\
h_{2^{\prime}}=\frac{\dot{m}_{1} h_{1^{\prime}}+W_{p}}{\dot{m}_{1}} \\
=200.99 \frac{\mathrm{kJ}}{\mathrm{kg}}
\end{gathered}
$$

For enthalpy values in state 3 to state 5 were the same as at initial conditions, because this modification was planned for fuel economy in the boiler. The temperature changed only occurs at point 1 and point 2 .

State 7:

To determine the enthalpy at state 7 , the law of conservation of energy was used.

$$
\begin{aligned}
\dot{m}_{1}\left(h_{1^{\prime}}-h_{7}\right) & =\dot{m}_{5}\left(h_{5}-h_{6}\right) \\
0.2 \frac{\mathrm{kg}}{\mathrm{s}}(188.44-125.74) & =0.084 \frac{\mathrm{kg}}{\mathrm{s}}\left(288.88-h_{7}\right) \\
h_{7} & =139.52 \frac{\mathrm{kJ}}{\mathrm{kg}}
\end{aligned}
$$

The value of the steam cycle efficiency was expressed in the form of heat transfer using the ratio of the amount of heat out to the heat entering the boiler.

$$
\begin{aligned}
q_{\text {in }} & =\left(h_{3}-h_{2^{\prime}}\right) \\
& =2497.61 \frac{\mathrm{kJ}}{\mathrm{kg}} \\
q_{\text {out }} & =\left(h_{4}-h_{1^{\prime}}\right) \\
& =1609.46 \frac{\mathrm{kJ}}{\mathrm{kg}} \\
w_{\text {net }} & =q_{\text {in }}-q_{\text {out }} \\
& =940.85 \frac{\mathrm{kJ}}{\mathrm{kg}}
\end{aligned}
$$

then the efficiency of the steam cycle

$$
\begin{aligned}
\eta_{\text {Steamcycle }} & =\frac{w_{\text {net }}}{q_{\text {in }}} \times 100 \% \\
& =37.67 \%
\end{aligned}
$$

While the fuel consumption for the steam cycle with the close FWH method and with a boiler efficiency of $85.46 \%$ can be calculated from equation 2 .

$$
\begin{aligned}
\dot{m}_{b b}^{\prime} \times G C V \text { gas } x \eta_{\text {Boiler }} & =\dot{m}_{\text {watrer }}^{\prime} \times\left(h 3-h 2^{\prime}\right) \\
\dot{m}_{b b}^{\prime} & =\frac{\dot{m}_{\text {water }}^{\prime} \times\left(h 3-h 2^{\prime}\right)}{L H V L N \times \eta_{\text {Boiler }}} \\
& =0.0117 \frac{\mathrm{kg}}{\mathrm{s}}
\end{aligned}
$$

3.3 The Efficiency of Steam Cycle for Open FWH Method In the modified condition of the planned cycle, the steam coming out of the separator is fed into the open FWH (Feed 
Water Heater). Open FWH is mixed with feed water. As shown in Figure 6.

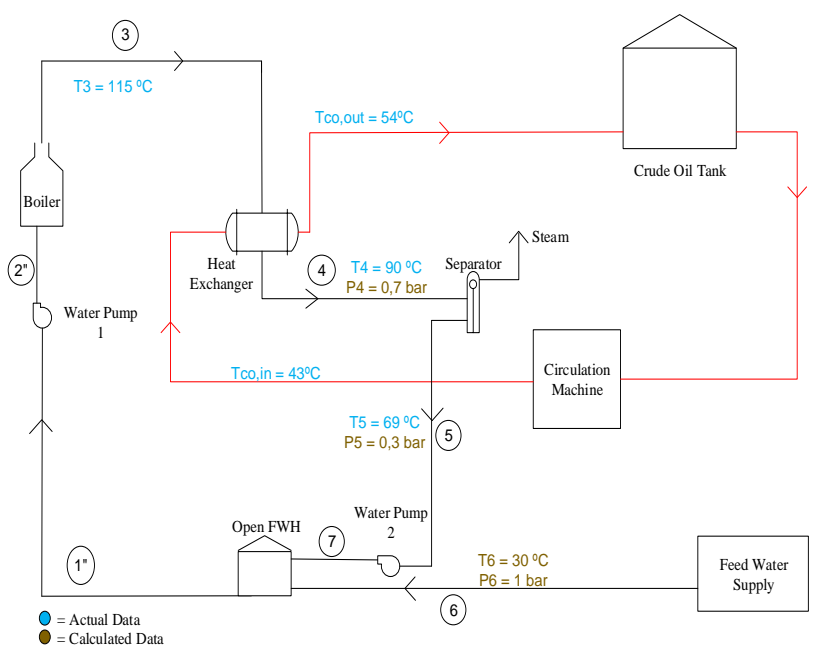

Figure 6: Modification of the Steam Cycle Using Open FWH Method

To calculate the efficiency of the cycle, the enthalpy value of each state was needed. By using Figure 7, for the modified state there had been a temperature change marked with the symbol (“):

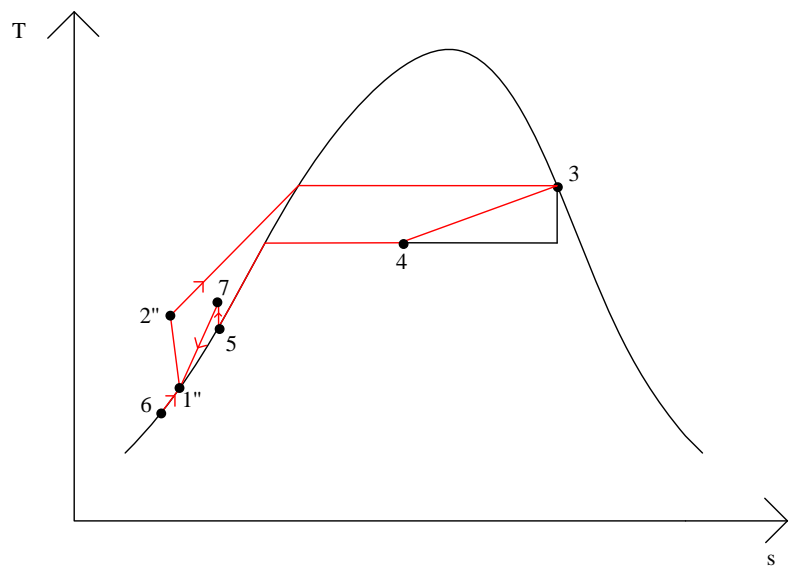

Figure 7: T-s Diagram Modified Open FWH

State 1":

State 1" was in a saturated water condition. To determine the value of temperature change in state 1", the law of conservation of energy was used. The mass flow rate of state 6 was $58 \%$ from $0.2 \mathrm{~kg} / \mathrm{s}$, then $0.2 .58 \%=0.116 \mathrm{~kg} / \mathrm{s}$.

To calculate the work of the water pump 2 using the equation:

$$
\begin{aligned}
\dot{W}_{p 2} & =\dot{V}_{6}\left(P_{7}-P_{5}\right) \\
& =0,001022 \frac{\mathrm{m} 3}{\mathrm{~s}}(100-30) k P a\left[\frac{1 \mathrm{~kJ}}{1 \mathrm{kPa} \mathrm{m}^{3}}\right] \\
& =\frac{0,07154 \frac{\mathrm{kJ}}{\mathrm{s}}}{0,084 \frac{\mathrm{kg}}{\mathrm{s}}}
\end{aligned}
$$

$$
=0.8516 \frac{\mathrm{kJ}}{\mathrm{kg}}
$$

To calculate the enthalpy at point 7 use the equation:

$$
\begin{aligned}
\dot{W}_{p 2} & =h_{7}-h_{5} \\
h_{7} & =h_{5}+\dot{W}_{p 2} \\
& =288.88+0.8516 \\
& =289.73 \frac{\mathrm{kJ}}{\mathrm{kg}}
\end{aligned}
$$

Then the value of enthalpy and entropy at state 1 " can be seen in Table 7.

Table 7: Enthalpy and Entropy Values at $\mathrm{T}_{1}$ "

\begin{tabular}{ccc}
\hline $\mathrm{h}(\mathrm{kJ} / \mathrm{kg})$ & $\mathrm{T}\left({ }^{\circ} \mathrm{C}\right)$ & $\mathrm{s}(\mathrm{kJ} / \mathrm{kg} \cdot \mathrm{K})$ \\
\hline 188.44 & 45.00 & 0.6386 \\
194.63 & 46.40 & 0.6579 \\
209.34 & 50.00 & 0.7038 \\
\hline
\end{tabular}

State 2":

State 2" is in a saturated water condition, to calculate the enthalpy in state 2", the law of conservation of energy was used. The value of $\mathrm{Wp}$ is used in the calculation of the initial conditions.

$$
\begin{aligned}
h_{2^{\prime \prime}} & =\frac{\dot{m}_{1^{\prime \prime}} h_{1^{\prime \prime}}+\dot{w}_{p}}{\dot{m}_{1}} \\
& =\frac{\left(0,2 \frac{\mathrm{kg}}{\mathrm{s}}\right)\left(194,63 \frac{\mathrm{kJ}}{\mathrm{kg}}\right)+2,51 \frac{\mathrm{kJ}}{\mathrm{s}}}{\frac{0,2 \mathrm{~kg}}{\mathrm{~s}}} \\
& =207.18 \frac{\mathrm{kJ}}{\mathrm{kg}}
\end{aligned}
$$

Steam cycle efficiency

$$
\begin{aligned}
q_{\text {in }} & =\left(h_{3}-h_{2^{\prime \prime}}\right) \\
& =2491.42 \frac{\mathrm{kJ}}{\mathrm{kg}} \\
q_{\text {out }} & =\left(h_{4}-h_{1^{\prime \prime}}\right) \\
& =1550.57 \frac{\mathrm{kJ}}{\mathrm{kg}} \\
w_{\text {net }} & =q_{\text {in }}-q_{\text {out }} \\
& =940.85 \frac{\mathrm{kJ}}{\mathrm{kg}}
\end{aligned}
$$

Then the efficiency of the steam cycle:

$$
\begin{aligned}
\eta_{\text {Steamcycle }} & =\frac{w_{\text {net }}}{q_{\text {in }}} \times 100 \% \\
& =37.76 \%
\end{aligned}
$$


While the fuel consumption for the steam cycle with the open FWH method and with a boiler efficiency of $69.3 \%$ can be calculated from equation 2 .

$$
\begin{aligned}
m_{-} b b " x G C V & \text { gas } x \eta_{\_} \text {Boiler }=m_{-} \text {water } " \times\left(h 3-h 2^{\prime \prime}\right) \\
m_{-} b b " & =\frac{\dot{m}_{\text {water }} " \times\left(h 3-h 2^{\prime \prime}\right)}{L H V L N G \times \eta_{\text {Boiler }}} \\
& =0.0116 \mathrm{~kg} / \mathrm{s}
\end{aligned}
$$

\subsection{CONCLUSION}

The average efficiency of the steam cycle of PT. Pertamina EP Asset 1 Lirik Field was $36.74 \%$. And, after modified steam cycle, the efficiency in the closed FWH modified steam cycle was $37.67 \%$. The efficiency in the open FWH modified steam cycle was $37.76 \%$. The efficiency of the steam cycle increased after modification plan, which was carried out using the close FWH and open FWH methods. The comparison of efficiency can be seen in Figure 8.

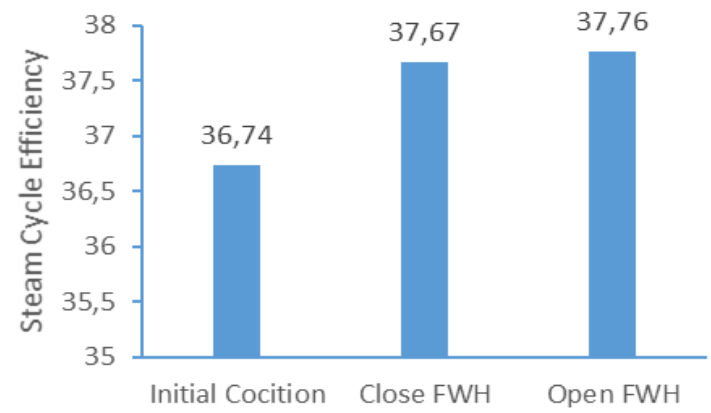

Figure 8: Steam Cycle Average of Energy Efficiency Comparison

\section{ACKNOWLEDGEMENTS}

The author acknowledges the management and field staff of Section of Mechanics, Operators and Instrumentation staff in the Pertamina EP Asset 1 Lirik Field, Lirik, Riau, Indonesia for supports these research activities.

\section{REFERENCES}

[1] Sorrell, S. (2015) Reducing energy demand: A review of issues, challenges and approaches, Renewable and Sustainable Energy Reviews, 47, 74-82.

[2] Martin, A., Wahab, H., \& Barbarosa, M. (2021). Coalbed methane as a new source of energy in Indonesia and some developed countries; a review, Journal of Ocean, Mechanical and Aerospace -Science and Engineering-, 65(2), 40-60.

[3] De la Cruz, L.C, Perea, M.A.J., De la Cruz-Fernández, J.L., Alvarez, B.J.A. \& Manzano, A.F. (2017). Worldwide research on energy efficiency and sustainability in public buildings. Sustainability, 9(8):1294.

[4] Priambodo, D., Dewita, E. \& Irianto, I.D. (2015). Analisis energi dan eksergi pada sistem HTR-10 siklus turbin uap, Jurnal Pengembangan Energi Nuklir, 17(1), 33-43.

[5] Santoso, H. (2018). Optimalisasi untuk menghasilkan efisiensi ideal turbin uap pembangkit listrik tenaga biomassa kapasitas $20 \mathrm{Mw}$, Jurnal STRING, 3(2), 181188.

[6] Riska, Simanjuntak, Y.M. \& Taufiqurrahman, M. (2019). Studi nilai efisiensi termal penggunaan feedwater heater PT. Indonesia Power UJP PLTU Sanggau, Jurnal Teknologi Rekayasa Teknik Mesin, 1(1), 1-7,

[7] Reynolds \& Perkins. (1977). Engineering Thermodynamic. (2 $2^{\text {nd }}$ Ed.), McGraw-Hill.

[8] Atkins, P.W. (1999). Kimia Fisika Jilid II. Erlangga, Jakarta.

[9] Muin A.S. (Ed.). (1998). Pesawat-Pesawat Konversi Energi I (Ketel Uap). CV. Rajawali.

[10] Hariyanto, B. \& Romy, R. (2020). Maintenance schedule optimization for turnaround hot gas path inspection of gas turbine in north duri cogeneration plant using impact method, Journal of Ocean, Mechanical and Aerospace Science and Engineering-, 64(1), 25-32.

[11] Priayana, S.P. (2017). Menghitung efisiensi boiler sebagai sistem pembangkit tenaga uap, Jurnal Sains \& Teknologi, 1(1), 102-123.

[12] Cengel, Y.A., Boles, M.A., \& Mehmet, A. (2019). Thermodynamic an Engineering Approach. (9 $9^{\text {th }}$ ed.), New York: Mc Graw-Hill Education. 